Vol. 24, No. 3, Juli 2021, hlm. 380-390

p-ISSN: 1410-9344; e-ISSN: 2549-5631

WARTA LPM

homepage: http://journals.ums.ac.id/index.php/warta

\title{
Peningkatan Keterampilan Berbicara sebagai Upaya Kaderisasi Khatib pada Remaja Masjid
}

\author{
Miftakhul Huda \\ Program Studi Pendidikan Bahasa dan Sastra Indonesia, Fakultas Keguruan dan Ilmu Pendidikan \\ Universitas Muhammadiyah Surakarta \\ Surel: miftakhul.huda@ums.ac.id
}

\begin{tabular}{l}
\hline \multicolumn{1}{c}{ Article Info } \\
\hline Submitted: 25 December 2020 \\
Revised: 8 Mey 2021 \\
Accepted: 6 June 2021 \\
Published: 20 July 2021
\end{tabular}

Keywords: speaking skills, sermon, training

\begin{abstract}
The purpose of this service is to improve speaking skills in the form of a sermon. Participants were given preaching materials and training. Community service in the form of regeneration of preachers through improving speaking skills was carried out in three places, namely the Clolo Village Mosque, East Paulan Hamlet Head House, Colomadu sub-district, and Al Musyafirin Mosque Surakarta. Community service was carried out on 10,11, and 12 December 2019. This activity was carried out in several stages. In the first stage, initial observations that aims to obtain information about the initial conditions of the target candidates for this community service activity. In addition to initial observations, program planning is also included in the first stage. Program planning includes the preparation of proposals, administrative preparation, licensing, and preparation of activity designs. Secondly, the implementation stage that consists of several activities, including the provision of material, pretest, training, posttest, and feedback. Lastly, the evaluation stage includes the preparation of reports, preparation of publication articles, and follow-up plans. After joining this activity, participants do independent exercises and at least $50 \%$ of the total participants appear as preachers for Friday prayers. The number of service participants in these three locations is 16 people. Thus, the target of this dedication is 8 brave people appeared as a preacher for Friday prayers. Community service in the form of speaking skills training as an effort to regenerate preachers in three places, namely the Clolo Village Mosque, Paulan Hamlet Head's House East, Colomadu District, and Al Musyafirin Mosque Surakarta included in the successful category. A total of 93, 75\% of the participants who participating in community service has increased the value of pretest to posttest. Participants' prior knowledge related to sermons, mosques are intense in conducting religious studies, the intensity of training preaching, and the activeness of participants to take part in the study is the cause of the success of the participants to become preachers.
\end{abstract}


Kata kunci: keterampilan berbicara, khotbah, pelatihan

\section{Abstrak}

Tujuan pengabdian ini adalah meningkatkan keterampilan berbicara dalam bentuk khotbah. Jenis pengabdian masyarakat ini adalah pelatihan. Peserta diberikan materi dan pelatihan berkhotbah. Pengabdian masyarakat berupa kaderisasi khatib melalui peningkatan keterampilan berbicara dilaksanakan di tiga tempat, yaitu Masjid Desa Clolo, Rumah Kepala Dusun Paulan Timur, kecamatan Colomadu, dan Masjid Al Musyafirin Surakarta. Pengabdian masyarakat dilaksanakan pada 10, 11, dan 12 Desember 2019. Pengabdian masyarakat ini dilaksanakan melalui beberapa tahapan. Pada tahap pertama dilakukan observasi awal.Observasi awal dilakukan untukmendapatkan informasi tentang kondisi awal calon sasaran kegiatan pengabdian masyarakat ini. Selain observasi awal, perencanaan program juga termasuk dalam tahap pertama. Perencanaan program meliputi penyusunan proposal, persiapan administrasi, perizinan, dan penyusunan desain kegiatan. Tahap kedua merupakan tahap pelaksanaan. Tahap pelaksanaan terdiri dari beberapa kegiatan, di antaranya pemberian materi, pretest, pelatihan, postest, dan umpan-balik. Tahap ketiga merupakan tahap evaluasi. Tahap evaluasi meliputi penyusunan laporan, penyusunan artikel publikasi, dan rencana tindak lanjut. Tindak lanjut dari kegiatan pengabdian masyarakat ini adalah peserta melakukan latihan mandiri dan minimal 50\% dari jumlah peserta tampil sebagai khatib salat Jumat. Jumlah peserta pengabdian di tiga lokasi ini adalah 16 orang. Dengan demikian, target pengabdian ini 8 orang berani tampil sebagai khatib salat Jumat. Pengabdian masyarakat berupa pelatihan keterampilan berbicara sebagai upaya kaderisasi khatib di tiga tempat, yaitu Masjid Desa Clolo, Rumah Kepala Dusun Paulan Timur, Kecamatan Colomadu, dan Masjid Al Musyafirin Surakarta termasuk ke dalam kategori berhasil. Sebanyak 93, 75\% peserta yang mengikuti pengabdian masyarakat mengalami peningkatan nilai dari pretest ke postest. Pengetahuan awal peserta terkait dengan khotbah, masjid intens dalam mengadakan kajian keagamaan, intensitas latihan berkhotbah, dan keaktifan peserta untuk mengikuti kajian merupakan penyebab keberhasilan peserta menjadi khatib.

\section{PENDAHULUAN}

Kaderisasi merupakan hal penting bagi keberlanjutan organisasi. Kaderisasi merupakan upaya menyiapkan calon pengganti kepemimpinan sebuah organisasi. Kader merupakan orang-orang terbaik atau orangorang pilihan yang memiliki kecakapan dan kemampuan tertentu dalam organisasi. Kaderisasi tidak sekadar menyiapkan sosok pengganti kepengurusan organisasi, tetapi juga proses penyiapan kader.

Pimpinan yang baik adalah pimpinan yang sadar bahwa kepemimpinan akan diteruskan oleh generasi di bawahnya, sehingga seorang pemimpinmemilikikewajibanuntukmenyiapkan calon pemimpin (Kruel, Horne, Steenis, \& Penuel, 2018). Kaderisasi bukan sebuah proses yang instan. Kaderisasi membutuhkan waktu yang lama dan terkonsep. Terkonsep yang dimaksud adalah kaderisasi perlu dirumuskan dengan baik (Clark, 2016). Rumusan tersebut di antaranya adalah kompetensi apa yang diperlukan sehingga untuk mencapai itu kader memerlukan materi dan kesempatan berkiprah pada medan tertentu.

Kaderisasi atau proses menyiapkan penerus yang berkualitas di antaranya adalah khatib. Khatib merupakan orang yang khotbah. 
Dengan demikian, khatib merupakan seorang pendakwah. Sebagai seorang pendakwah, khatib harus menguasai materi keagamaan. Selain itu, khatib sangat perlu memiliki keterampilan berbicara. Keterampilan berbicara yang mumpuni diperlukan khatib agar materi ceramah atau seruan kepada umat menarik, sehingga didengarkan dan umat mengikuti seruannya.

Berdasarkan observasi awal sebagai dasar analisis situasi diperoleh informasi bahwa tidak banyak khatib muda di beberapa masjid di sekitar Surakarta. Khatib di masjid Surakarta dan sekitarnya didominasi oleh ustaz senior. Hal ini dipandang sebagai satu kelemahan. Kaderisasi pendakwah, termasuk khatib, perlu dilakukan secara berkesinambungan. Kontinuitas diperlukan karena regenerasi umat selalu berlangsung, sehingga pendakwah harus selalu ada.

Pada era milenial, jemaah memerlukan dakwah yang bersifat komprehensif. Perkembangan media dan telekomunikasi tidak jarang menyajikan informasi yang bersifat hoax, termasuk informasi keagamaan (Turner, 2012). Oleh karena itu, pendakwah memiliki pengaruh dalam meluruskan dan memberikan wawasan keagamaan yang benar sesuai dengan tuntunan Nabi Muhammad Saw. melalui penggunaan bahasa yang baik.

Peningkatan keterampilan berbicara tidak sekadar mampu memilih diksi yang tepat sehingga dapat dipahami oleh audiens. Keterampilan berbicara juga meliputi penguasaan emosi (Ram, Asaei, \& Bourlard, 2018). Penguasaan emosi akan berpengaruh pada penguasaan materi (Steinerov, 2016). Bagi pembelajar pemula, bisa terjadi materi yang telah disiapkan dan disusun dengan baik tidak mampu disampaikan secara sistematis dan menarik karena nervous atau gugup berbicara di depan umum (Ariel \& Iris, 2019). Penguasaan emosi memerlukan latihan. Pembicara perlu beberapa kali berlatih untuk berbicara di depan umum dalam rangka menyiapkan mental.

Permasalahan kemampuan berbicara masih menjadi kendala bagi khatib pemula. Meskipun khatib pemula biasa menggunakan teks dalam berkhotbah, improvisasi tetap diperlukan. Hal ini penting agar khotbah tidak terasa monoton. Komunikasi satu arah dalam khotbah perlu menarik sehingga materi yang disampaikan dapat diterima jemaah dengan tepat. Apabila khatib selalu membaca teks khotbah yang dibawa, kemungkinan yang terjadi adalah jemaah merasa bosan dan intonasi monoton. Oleh karena itu, pelatihan keterampilan berbicara sangat diperlukan dalam kaderisasi khatib.

Dalam pembelajaran berbicara dilakukan beberapa tahapan. Pertama, menyiapkan materi yang disampaikan. Kedua, melihat model atau contoh berbicara di depan umum. Ketiga, berlatih berbicara dengan audiens terbatas. Keempat, memulai berbicara di depan umum. Pelaksanaan pembelajaran berbicara dalam bentuk khotbah yang dilakukan secara tertib dan sistematis diharapkan dapat menjadi salah satu bentuk kaderisasi khatib di beberapa masjid di Surakarta dan sekitarnya.

Mitra dalam pengabdian masyarakat ini adalah Remaja Masjid Al Musafirin Surakarta, Remaja Masjid Desa Clolo Kadipiro Surakarta, dan Remaja Masjid Dusun Paulan Colomadu Karanganyar. Ketiga masjid tersebut memiliki jemaah pemuda yang aktif, tetapi regenerasi khatib belum maksimal. Permasalahan yang muncul dalam tersendatnya kaderisasi khatib adalah kurangnya percaya diri remaja masjid untuk tampil sebagai khatib. Di samping itu, ruang yang diberikan kepada remaja masjid untuk menjadi khatib juga belum maksimal.

Pengabdian masyarakat ini memberikan kesempatan remaja masjid untuk berlatih menjadi khatib. Peserta praktik menjadi khatib satu persatu sehingga semua memiliki pengalaman tampil. Selain itu, peserta diberikan materi tentang rukun wajib dan sahnya khotbah.

Di samping permasalahan, mitra sebenarnya memiliki potensi. Potensi yang dimiliki oleh remaja masjid adalah intelektualitas. Para remaja masjid adalah kaum terpelajar. Dengan demikian, remaja masjid tidak kesulitan dalam hal penyiapan materi khotbah sehingga pengabdian ini tidak fokus pada bagaimana menyiapkan dan memilih materi khotbah, tetapi bagaimana menyampaikan materi khotbah.

Peningkatan keterampilan berbicara para calon khatib dilakukan dengan beberapa tahapan. Tahap pertama adalah pendalaman materi. Calon khatib diberikan materi tentang khotbah, 
yaitu syarat dan rukun sahnya khotbah. Selain itu, calon khatib diberikan materi tentang adab berkhotbah. Hal ini penting karena para calon khatib diharapkan tampil sebagai pendakwah. Tahap kedua adalah pemodelan. Pemodelan ini membeikan kesempatan dan referensi kepada calon khatib untuk mengamati ulama senior dalam berkhotbah. Dengan pemodelan ini, para calon khatib dapat mengambil pelajaran dari para ulama tentang gaya berkhotbah. Para calon khatib dapat meniru gaya atau mengembangkan gaya para ulama dalam menyampaikan materi. Tahap ketiga adalah praktik berkhotbah. Pada tahap ini para calon khatib diberikan kesempatan menyampaikan materi yang telah disusun. Peserta pengabdian masyarakat satu persatu menampilkan performansinya. Hal ini penting agar para calon khatib mendapatkan pengalaman autentik. Dasar dari pelatihan keterampilan adalah latihan. Semakin sering latihan, memperoleh hasil semakin baik.

Kemampuan sebelum memperoleh materi dan setelah memperoleh materi dilihat peningkatan atau penurunannya. Aspek yang dinilai, yaitu kualitas materi, pemilihan diksi, tempo, nada, dan penguasaan audiens. Di akhir sesi, peserta diberikan umpan balik sehingga mengetahui kekurangan dan kelebihan dalam menyampaikan khotbah masing-masing. Dengan demikian, tujuan pengabdian masyarakat ini adalah meningkatkan keterampilan berbicara dalam bentuk khotbah.

\section{METODE}

Jenis pengabdian masyarakat ini adalah pelatihan. Peserta diberikan materi dan pelatihan berkhotbah. Khotbah merupakan salah satu keterampilan berbicara. Melatih berkhotbah merupakan salah satu aspek dalam melatih keterampilan berbicara. Meskipun demikian, pelatihan tidak sekadar memberikan kesempatan peserta untuk praktik khotbah. Namun, peserta terlebih dahulu diberikan materi tentang khotbah sehingga peserta memiliki pengetahuan dasar. Pengabdian masyarakat berupa kaderisasi khatib melalui peningkatan keterampilan berbicara dilaksanakan di tiga tempat, yaitu Masjid Desa Clolo, Rumah Kepala Dusun Paulan Timur, Kecamatan Colomadu, dan Masjid Al Musyafirin Surakarta. Pengabdian masyarakat dilaksanakan pada 10, 11, dan 12 Desember 2019.

Pengabdian masyarakat ini dilaksanakan melalui beberapa tahapan. Pada tahap pertama dilakukan observasi awal. Observasi awal dilakukan untuk mendapatkan informasi tentang kondisi awal calon sasaran kegiatan pengabdian masyarakat ini. Selain observasi awal, perencanaan program juga termasuk dalam tahap pertama. Perencanaan program meliputi penyusunan proposal, persiapan administrasi, perizinan, dan penyusunan desain kegiatan. Tahap kedua merupakan tahap pelaksanaan. Tahap pelaksanaan terdiri dari beberapa kegiatan, di antaranya pemberian materi, pretest, pelatihan, postest, dan umpanbalik. Tahap ketiga merupakan tahap evaluasi. Tahap evaluasi meliputi penyusunan laporan, penyusunan artikel publikasi, dan rencana tindak lanjut. Tindak lanjut dari kegiatan pengabdian masyarakat ini adalah peserta melakukan latihan mandiri dan minimal 50\% dari jumlah peserta tampil sebagai khatib salat Jumat. Jumlah peserta pengabdian di tiga lokasi ini adalah 16 orang. Dengan demikian, target pengabdian ini 8 orang berani tampil sebagai khatib salat Jumat.

\section{HASIL DAN PEMBAHASAN}

Pengabdian masyarakat dalam bentuk pelatihan keterampilan berbicara sebagai salah satu wujud kaderisasi khatib dilakukan dengan kegiatan awal berupa pemberian materi. Materi yang diberikan kepada peserta adalah pengetahuan umum terkait khotbah. Pengetahuan umum tersebut di antaranya adalah pengertian khotbah, syarat sah khotbah, rukun, dan wajib khotbah. Pengetahuan umum ini berfungsi agar peserta memahami ilmu khotbah sebelum praktik (Huda, 2018b). Dengan demikian, ketika peserta praktik khotbah telah mengetahui tata cara dan adab berkhotbah. Tahap pemberian materi dilakukan dengan metode ceramah dan diskusi. Ceramah dilakukan untuk menyampaikan materi utama dan pokok pembahasan. Setelah itu, pendalaman materi dilakukan dengan cara diskusi dan tanyajawab. Peserta menanyakan hal-hal yang belum dipahami atau membahas permasalahan yang bersifat kasuistik. 
Tabel 1. Nilai Pretest Peserta di Masjid Desa Clolo

\begin{tabular}{clc}
\hline No & Inisial Nama Peserta & Nilai Pretest \\
\hline 1 & IAP & 65 \\
2 & SIS & 60 \\
3 & SOM & 45 \\
4 & JMM & 65 \\
5 & AAP & 50 \\
6 & AJ & 40 \\
\hline
\end{tabular}

Tabel 2. Nilai Pretest Peserta Masjid Dukuh Paulan

\begin{tabular}{clc}
\hline No. & Inisial Nama Peserta & Nilai Pretest \\
\hline 1. & $\mathrm{Yg}$ & 59 \\
2. & $\mathrm{Al}$ & 72 \\
3. & $\mathrm{Fb}$ & 54 \\
4. & $\mathrm{Ag}$ & 56 \\
5. & $\mathrm{Pr}$ & 60 \\
\hline
\end{tabular}

Tabel 3. Nilai Pretest Peserta Masjid Al Musyafirin

\begin{tabular}{clc}
\hline No. & Inisial Nama Peserta & Nilai Pretest \\
\hline 1. & $\mathrm{Md}$ & 83 \\
2. & $\mathrm{Am}$ & 83 \\
3. & $\mathrm{Rq}$ & 83 \\
4. & $\mathrm{Mu}$ & 84 \\
5. & $\mathrm{Ft}$ & 80 \\
\hline
\end{tabular}

Sebelum peserta diberikan materi perihal khotbah, terlebih dahulu dilakukan pretest. Pretestberfungsiuntuk mengetahui pengetahuan awal peserta tentang khotbah. Semua peserta pernah mendengarkan khotbah, tetapi belum pernah menjadi khatib. Oleh karena itu, pretest ini sekaligus berfungsi menggali ingatan peserta dan merumuskan pengalaman yang pernah dialami ketika mendengarkan khotbah.

Aspek yang dinilai dalam pretest $\mathrm{di}$ antaranya adalah materi khotbah, tata cara khotbah, syarat sah khotbah, rukun khotbah, dan praktik khotbah. Masing-masing peserta dinilai lima aspek tersebut. Skor setiap aspek berkisar antara 1-20. Dengan demikian, skor maksimal adalah 100. Hasil pretest di tiga lokasi, yaitu Masjid Desa Clolo, Masjid Dukuh Paulan, dan
Masjid Almusyafirin menunjukkan variasi nilai yang beragam.

Hasil pretest dari keenam peserta pada tabel 1 menunjukkan nilai yang kurang. Untuk mencapai kemampuan minimal, setidaknya peserta mencapai nilai 70. Dua peserta mencapai nilai 65, artinya mendekati standar minimal. Namun, peserta lain masih memiliki nilai yang kurang. Kelemahan dari peserta pada aspek pengetahuan tata cara khotbah dan praktik khotbah. Kondisi demikian dapat terjadi karena peserta belum pernah berkhotbah, sehingga ketika praktik ada rasa cemas dan kurang percaya diri akhirnya berpengaruh pada performa. Latihan merupakan kunci untuk meningkatkan keterampilan (Huda, Kustanti, \& Rufiah, 2019).

Tabel 2 menunjukkan ada lima orang yang menjadi peserta pengabdian masyarakat. Dari lima peserta, hanya ada satu orang yang nilai pretest mencapai 70 . Nilai rata-rata pretest pada lokasi kedua ini adalah 60, 2. Dengan demikian, empat peserta memiliki nilai di bawah ratarata. Kondisi demikian menunjukkan bahwa pengabdian masyarakat layak dilaksanakan dalam rangka untuk meningkatkan kompetensi peserta (Huda, 2018a). Seperti halnya pada lokasi pertama, kendala yang dialami peserta di lokasi kedua adalah pengetahuan tata cara khotbah dan praktik berkhotbah.

Lokasi ketiga dalam pengabdian masyarakat ini adalah Masjid $\mathrm{Al}$ Musyafirin. Tabel 3 menunjukkan bahwa peserta yang berjumlah lima orang telah mencapai nilai standar minimal, yaitu 70. Semua peserta di lokasi ketiga telah mencapai nilai di atas 80 , dengan rata-rata 82 , 6. Dengan demikian, semua peserta juga telah mencapai nilai di atas rata-rata. Kondisi demikian tidak terlepas dari latar belakang peserta dan lokasi. Peserta yang aktif sebagai remaja masjid dan aktif dalam kajian keagamaan memiliki potensi lebih besar dalam memperoleh nilai pretest. Selain itu, lokasi peserta yang berada di lingkungan yang sering mengadakan kajian keagamaan juga berpengaruh dalam perolehan nilai pretest peserta. Kemampuan berbicara tidak sekadar menunjukkan kompetensi individu. Keterampilan berbicara sangat didukung oleh lingkungan dan kesempatan untuk berlatih. Lingkungan yang positif sangat berkorelasi terhadap peningkatan keterampilan 
berbicara. Lingkungan yang positif tersebut di antaranya adalah lingkungan yang memberikan wawasan dan referensi untuk mengembangkan keterampilan berbicara. Oleh karena itu, dalam peningkatan keterampilan berbicara dilakukan pula dengan cara menciptakan lingkungan yang mendukung. Calon khatib yang berada di lingkungan yang sering mengadakan kajian dan aktif mengikutinya, wawasan atau materi pengetahuan agama akan meningkat sehingga akan berpengaruh dalam menyiapkan bahan khotbah.

Gambar 1 menunjukkan adanya perbedaan nilai prestes yang signifikan dari ketiga lokasi. Lokasi ketiga merupakan lokasi masjid di daerah kota, sedangkan lokasi 1 dan 2 berada di kabupaten. Hal ini bisa saja menjadi salah satu penyebab perbedaan pengetahuan awal peserta terkait dengan khotbah. Selain itu, lokasi ketiga lebih intens dalam mengadakan kajian keagamaan sehingga secara tidak langsung memberikan pengalaman dan pengetahuan kepada remaja masjid tersebut. Keaktifan masjid dalam mengadakan kajian keagamaan juga dapat menjadi faktor pengetahuan awal yang baik dari peserta pengabdian masyarakat (Raia, 2018). Meskipun demikian, hal ini perlu dilakukan penelitian lebih dalam. Kegiatan ini merupakan pengabdian kepada masyarakat, sehingga tidak melakukan penelitian terhadap perbedaan nilai pretest yang signifikan.

Tahap selanjutnya dalam pengabdian masyarakat ini adalah pemberian materi. Materi diberikan dengan ceramah dan diskusi. Materi yang diberikan di antaranya adalah syarat sah dan rukun khotbah. Materi ini sebagai bekal pengetahuan ketika peserta menjadi khatib. Berkhotbah tidak asal berbicara karena ada syarat syah dan rukun yang harus diperhatikan. Tanya-jawab dan diskusi memperdalam pengetahuan tentang materi yang disampaikan. Setelah peserta menerima materi tentang khotbah, pengabdian masyarakat dilanjutkan dengan praktik berkhotbah. Peserta satu persatu praktik berkhotbah, setelah sebelumnya membuat desain materi khotbah. Peserta bebas menentukan materi khotbah yang akan disampaikan dengan durasi kurang lebih 10 menit. Materi yang dipilih oleh peserta sebagai bahan untuk latihan berkhotbah di antaranya sabar, ikhlas, berbakti kepada orang tua, anjuran menahan marah, kisah sahabat rasul, dan keutamaan beribadah. Peserta mendapatkan dan menyusun materi dari hasil penelusuran internet yang dilakukan melalui ponsel masingmasing. Dalam menyampaikan materi, peserta masih relatif berpedoman pada teks. Peserta belum banyak bereksplorasi mambawa materi pada konteks kekinian. Peserta masih terlalu terpaku pada teks, sehingga interaksi dengan audiens masih minim (Anh, James, \& Pittock, 2018). Hal ini dapat di atasi dengan banyak berlatih. Dengan demikian, kendala yang dihadapi peserta dalam praktik khotbah adalah eksplorasi materi. Selain itu, peserta terkesan kurang percaya diri sehingga banyak konsep yang telah disusun menjadi lupa (Ma, Li, Liu, \& Zhang, 2018).

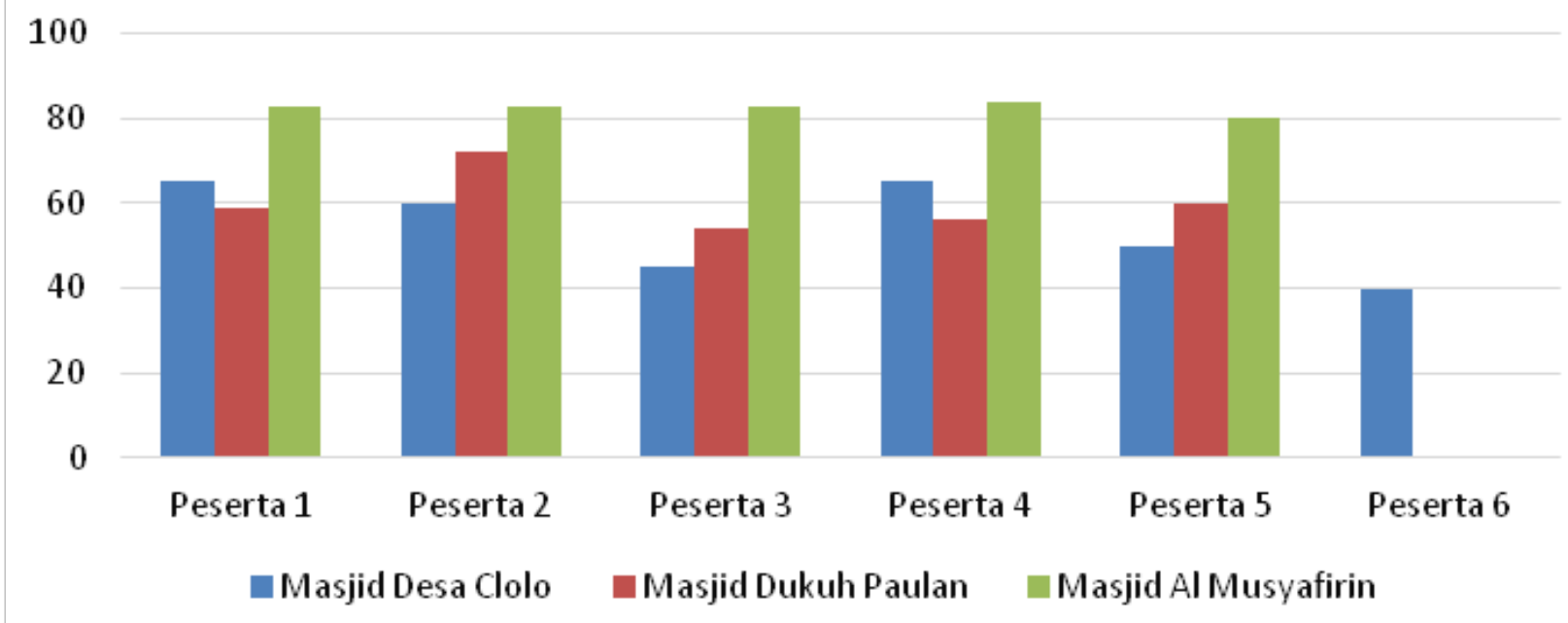

Gambar 1. Perbandingan Nilai Pretest di Tiga Lokasi Pengabdian Masyarakat 


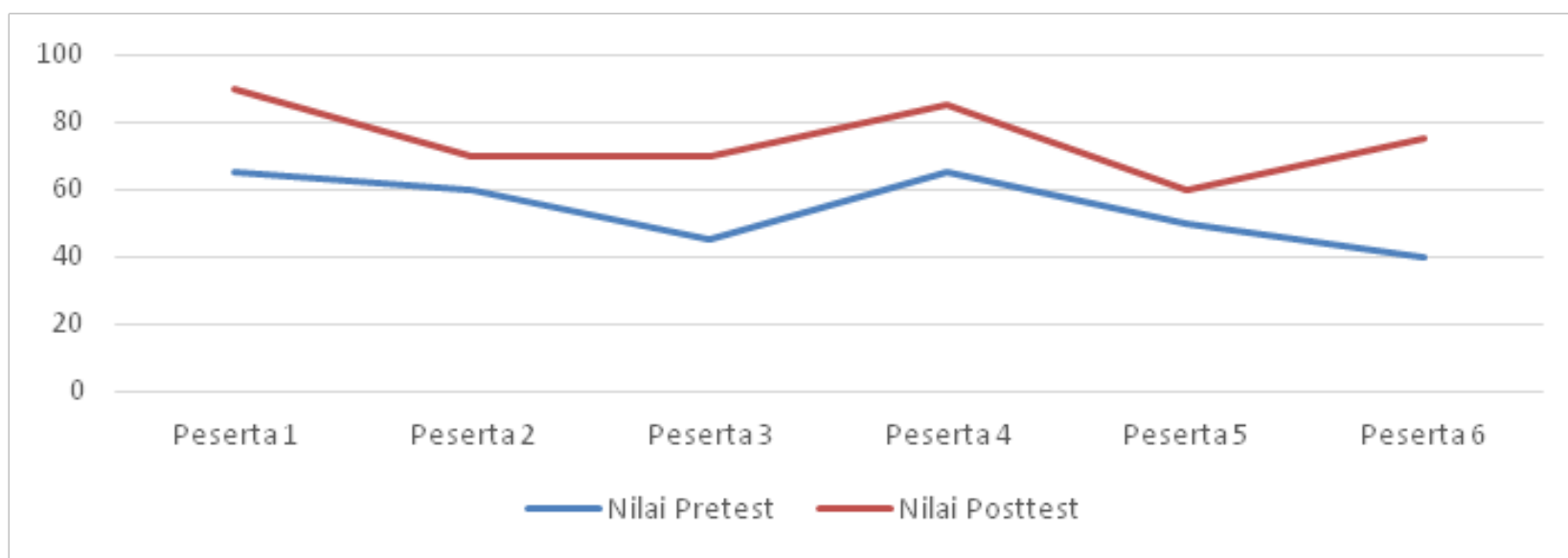

Gambar 2. Perbandingan Nilai Pretest dan Postest Peserta di Masjid Desa Clolo

Pada tahap selanjutnya adalah postest dan evaluasi. Postest dilakukan untuk melihat hasil dari pengabdian masyarakat yang telah berjalan. Evaluasi dilakukan untuk melakukan penilaian terhadap keberhasilan program. Dalam evaluasi, peserta dipersilakan memberikan masukan terhadap peningkatan program. Selain itu, peserta diminta untuk memberikan kesan selama mengikuti program pengabdian masyarakat. Kesan peserta yang mengikuti pengabdian masyarakat adalah positif. Peserta berharap kegiatan serupa dilakukan secara kontinu agar regenerasi khatib dapat berjalan.

Hasil dari postest yang dilakukan menunjukkan gambaran secara umum bahwa ada peningkatan pengetahuan dan kemampuan peserta. Peningkatan tersebut bervariasi antarpeserta. Selain itu, persentase kenaikannya juga beragam. Keragaman tersebut disebabkan karena keragaman kemampuan peserta. Selain kemampuan, minat dan keseriusan peserta mengikuti kegiatan berdampak pada hasil akhir penilaian. Peserta yang menerima masukkan dan serius melakukan perbaikan akan menunjukkan hasil akhir yang signifikan kenaikannya, sedangkan peserta yang mengikuti kegiatan sebagai bentuk kewajiban dan formalitas, hasilnya kurang maksimal bahkan cenderung stgnan.

Gambar 2 merupakan perbandingan nilai pretest dan postest di Masjid Desa Clolo. Gambar 2 memberikan gambaran bahwa semua peserta mengalami peningkatan nilai. Meskipun demikian, terdapat satu peserta yang nilainya masih berada di bawah standar minimal. Nilai standar minimal adalah 70, sedangkan peserta tersebut nilainya adalah 60. Kelima peserta lainnya telah berhasil mencapai nilai standar minimal. Kondisi demikian menunjukkan bahwa peserta perlu diberikan wawasan tentang khotbah. Materi tersebut di antaranya syarat, rukun, dan sunah khotbah. Khotbah tidak sama dengan berpidato biasa. Khotbah memiliki rukun, yaitu urutan yang harus dilalui secara urut oleh khatib. Apabila salah satu rukun itu tidak dilakukan menyebabkan khotbah menjadi tidak sah, sedangkan khotbah merupakan rangkaian dari salat.

Tabel 4. Rincian Nilai Peserta Masjid Clolo

\begin{tabular}{|c|c|c|c|c|c|c|c|c|c|c|c|c|c|}
\hline \multirow{2}{*}{ No } & \multirow{2}{*}{ Inisial Nama Peserta } & \multicolumn{5}{|c|}{ Pretest } & \multirow[t]{2}{*}{ skor } & \multicolumn{5}{|c|}{ Postest } & \multirow[t]{2}{*}{ skor } \\
\hline & & 1 & 2 & 3 & 4 & 5 & & 1 & 2 & 3 & 4 & 5 & \\
\hline 1 & IAP & 13 & 13 & 15 & 13 & 11 & 65 & 17 & 18 & 18 & 17 & 20 & 90 \\
\hline 2 & SIS & 11 & 11 & 12 & 12 & 13 & 59 & 14 & 14 & 13 & 15 & 15 & 71 \\
\hline 3 & SOM & 9 & 9 & 8 & 9 & 10 & 45 & 13 & 14 & 14 & 13 & 16 & 70 \\
\hline 4 & JMM & 13 & 13 & 13 & 13 & 13 & 65 & 16 & 15 & 15 & 18 & 19 & 83 \\
\hline 5 & AAP & 11 & 10 & 10 & 9 & 11 & 51 & 10 & 11 & 12 & 12 & 14 & 59 \\
\hline 6 & AJ & 5 & 5 & 3 & 4 & 8 & 40 & 15 & 15 & 15 & 14 & 16 & 75 \\
\hline
\end{tabular}




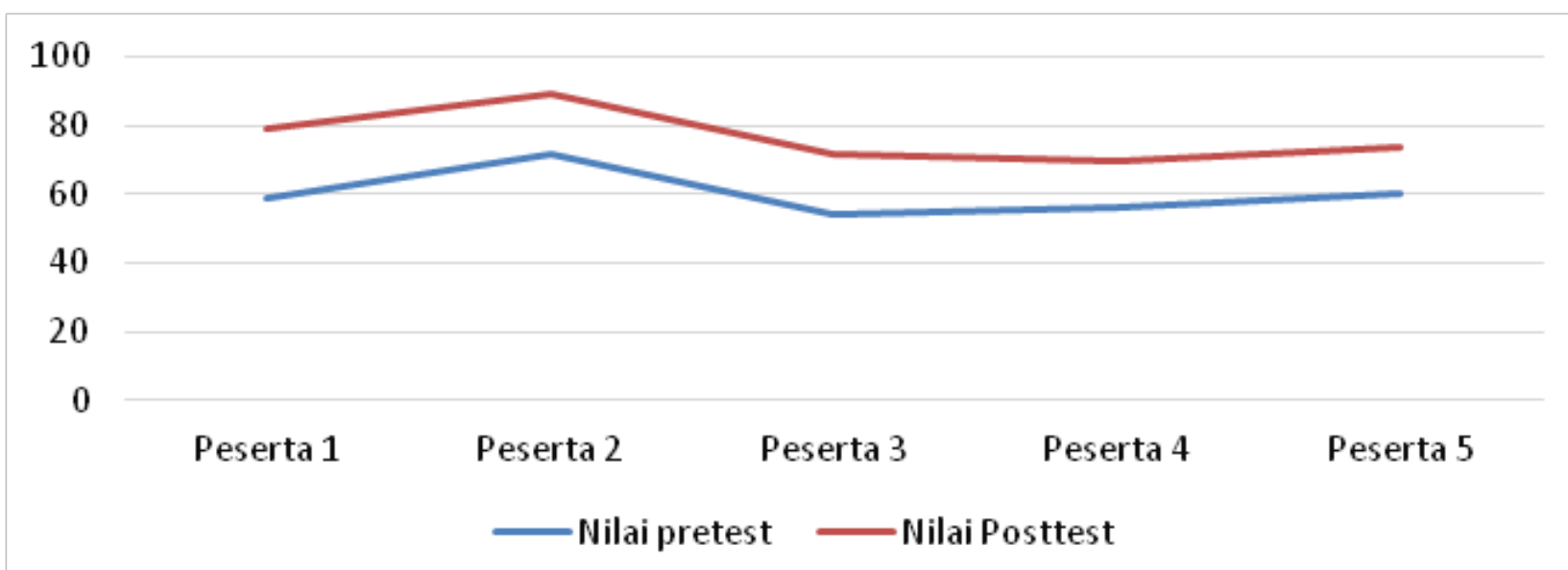

Gambar 3. Perbandingan Nilai Pretest dan Postest Peserta di Masjid Dukuh Paulan

Tabel 4 menunjukkan perbandingan nilai secara keseluruhan antar peserta, baik pretest maupun postest. Indikator kemampuan berkhotbah di antaranya adalah sebagai berikut: Pertama, kualitas materi khotbah. Kedua, pengetahuan tata cara berkhotbah. Ketiga, pengetahuan syarat sah khotbah. Keempat, penerapan rukun khotbah. Kelima, praktik khotbah, meliputi kelancaran, pemilihan diksi, dan kelogisan.

Kondisi serupa terjadi pada nilai postest peserta di Masjid Paulan. Gambar 3 menunjukkan bahwa semua peserta pengabdian mengalami peningkatan. Pada saat prestes, hanya ada satu peserta yang nilainya mencapai 70. Akan tetapi, nilai postest semua peserta lebih dari 70. Hal ini merupakan salah satu indikator keberhasilan pengabdian masyarakat untuk peningkatan keterampilan berbicara melalui khotbah. Keberhasilan ini dipengaruhi oleh beberapa faktor, di antaranya adalah dukungan dari teman sebaya. Dukungan dari orang lain mampu memberikan motivasi kepada seseorang (Shao \& Purpur, 2016). Hal ini terjadi pada peserta pengabdian. Dukungan tersebut diberikan dengan cara membarikan masukan atas kekurangan peserta dalam praktik berkhotbah. Masukan yang diberikan kepada peserta lain dikemas dengan bahasa yang tidak menyinggung dan diselipkan humor sehingga memecahkan ketegangan.

Tabel 5 merupakan dasar melakukan visualisasi gambar 3. Tabel 5 menunjukkan nilai pretest dan postest secara rinci. Secara umum kegiatan pengabdian masyarakat meningkatkan kemampuan peserta. Seperti halnya di Masjid Clolo, indikator kemampuan berkhotbah berjumlah lima. Pertama, kualitas materi khotbah. Kedua, pengetahuan tata cara berkhotbah. Ketiga, pengetahuan syarat sah khotbah. Keempat, penerapan rukun khotbah. Kelima, praktik khotbah, meliputi kelancaran, pemilihan diksi, dan kelogisan.

Tabel 5. Rincian Nilai Peserta Masjid Dukuh Paulan

\begin{tabular}{|c|c|c|c|c|c|c|c|c|c|c|c|c|c|}
\hline \multirow{2}{*}{ No. } & \multirow{2}{*}{ Inisial Nama Peserta } & \multicolumn{5}{|c|}{ Pretest } & \multirow{2}{*}{ skor } & \multicolumn{5}{|c|}{ Postest } & \multirow{2}{*}{ skor } \\
\hline & & 1 & 2 & 3 & 4 & 5 & & 1 & 2 & 3 & 4 & 5 & \\
\hline 1. & Yg & 11 & 11 & 12 & 12 & 13 & 59 & 15 & 16 & 16 & 16 & 16 & 79 \\
\hline 2. & $\mathrm{Al}$ & 13 & 14 & 14 & 14 & 17 & 72 & 18 & 18 & 17 & 18 & 18 & 89 \\
\hline 3. & $\mathrm{Fb}$ & 10 & 10 & 9 & 11 & 54 & 54 & 13 & 13 & 14 & 13 & 17 & 70 \\
\hline 4. & $\mathrm{Ag}$ & 10 & 10 & 10 & 13 & 13 & 56 & 14 & 14 & 13 & 14 & 16 & 71 \\
\hline 5. & $\operatorname{Pr}$ & 10 & 10 & 13 & 13 & 11 & 57 & 14 & 14 & 13 & 15 & 16 & 72 \\
\hline
\end{tabular}




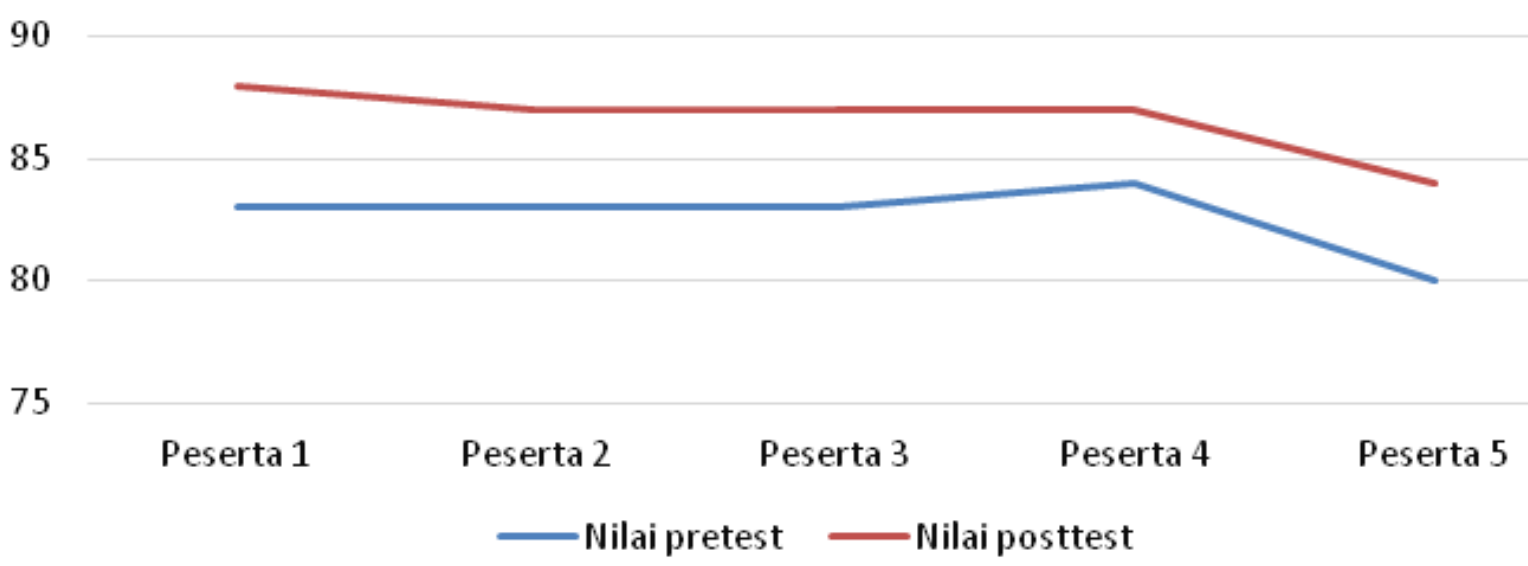

Gambar 4. Perbandingan nilai pretest dan postest peserta di Masjid Almusyafirin

Gambar 4 menunjukkan peningkatan nilai pretest ke postest. Nilai pretest peserta di Masjid Almusyafirin sudah di atas nilai standar minimal. Meskipun demikian, ada peningkatan nilai setelah diadakan pengabdian masyarakat. Peserta yang sebelumnya telah memiliki dasar yang baik terkait khotbah, dengan pengabdian masyarakat ini kemampuan peserta tersebut meningkat. Kunci dari peningkatan kemampuan tersebut adalah latihan (Bang \& Nadig, 2020). Semakin sering berlatih, akan semakin cepat mencapai keterampilan (Shishavan \& Shari, 2016). Selain berlatih, keterampilan berbicara dapat ditingkatkan dengan melihat para tokoh berpidato dan membaca buku. Kegiatan melihat para tokoh berpidato akan memberikan referensi bagaimana gaya berbicara di atas panggung dan di depan para pendengar. Kegiatan ini juga bermanfaat dalam mempelajari teknik ekspresi, dan penguasaan audiens. Kegiatan membaca buku akan berguna menambah wawasan dan pengetahuan calon khatib. Dengan teknik berbicara yang sangat tinggi sekalipun, pembicara tetap memerlukan materi yang akan disampaikan. Kegiatan membaca akan menjadi bekal bagi calon khatib menyusun materi khotbah.

Tabel 6 merupakan nilai keseluruhan peserta di Masjid Almusyafirin. Berdasarkan tabel 5 dapat diketahui bahwa secara keseluruhan terjadi peningkatan kemampuan peserta dalam berkhotbah. Hanya saja, persentase perubahan antarpeserta satu dengan peserta lain mengalami perbedaan. Seperti halnya di masjid lain, indikator kemampuan berkhotbah berjumlah lima. Pertama, kualitas materi khotbah. Kedua, pengetahuan tata cara berkhotbah. Ketiga, pengetahuan syarat sah khotbah. Keempat, penerapan rukun khotbah. Kelima, praktik khotbah, meliputi kelancaran, pemilihan diksi, dan kelogisan.

\section{SIMPULAN}

Pengabdian masyarakat berupa pelatihan keterampilan berbicara sebagai upaya kaderisasi khatib di tiga tempat, yaitu Masjid Desa Clolo, Rumah Kepala Dusun Paulan Timur, Kecamatan

Tabel 6. Rincian Nilai Peserta Masjid Almusyafirin

\begin{tabular}{|c|c|c|c|c|c|c|c|c|c|c|c|c|c|}
\hline \multirow{2}{*}{ No. } & \multirow{2}{*}{ Inisial Nama Peserta } & \multicolumn{5}{|c|}{ Pretest } & \multirow{2}{*}{ skor } & \multicolumn{5}{|c|}{ Postest } & \multirow{2}{*}{ skor } \\
\hline & & 1 & 2 & 3 & 4 & 5 & & 1 & 2 & 3 & 4 & 5 & \\
\hline 1. & $\mathrm{Md}$ & 17 & 16 & 16 & 16 & 18 & 83 & 18 & 18 & 17 & 17 & 20 & 90 \\
\hline 2. & $\mathrm{Am}$ & 17 & 16 & 16 & 16 & 18 & 83 & 17 & 16 & 17 & 17 & 19 & 86 \\
\hline 3. & $\mathrm{Rq}$ & 17 & 16 & 16 & 17 & 18 & 84 & 17 & 16 & 16 & 17 & 19 & 85 \\
\hline 4. & $\mathrm{Mu}$ & 17 & 17 & 15 & 18 & 19 & 84 & 17 & 16 & 17 & 17 & 20 & 87 \\
\hline 5. & $\mathrm{Ft}$ & 16 & 16 & 17 & 15 & 17 & 81 & 17 & 16 & 16 & 16 & 18 & 83 \\
\hline
\end{tabular}


Colomadu, dan Masjid Al Musyafirin Surakarta termasuk ke dalam kategori berhasil. Sebanyak 93, 75\% peserta yang mengikuti pengabdian masyarakat mengalami peningkatan nilai dari pretest ke postest. Pengetahuan awal peserta terkait dengan khotbah, masjid intens dalam mengadakan kajian keagamaan, intensitas latihan berkhotbah, dan keaktifan peserta untuk mengikuti kajian merupakan penyebab keberhasilan peserta menjadi khatib.

Saran pengabdian ini adalah kaderisasi khatib dapat berjalan dengan baik apabila peserta pengabdian diberikan kepercayaan untuk menjadi khatib. Oleh karena itu, peserta atau remaja masjid perlu disiapkan, baik materi, psikologi, maupun performansi. Upaya menyiapkan kader sangat tergantung pada keaktifan takmir masjid. Bagi pengabdian masyarakat selanjutnya, perlu menggarap ranah penyiapan materi. Konten untuk disampaikan sebagai materi khotbah tidak kalah penting apabila dibandingkan dengan performansi khatib ketika berkhotbah.

\section{PERSANTUNAN}

Tim pengabdian masyarakat mengucapkan terima kasih kepada Universitas Muhammadiyah Surakarta yang telah memberikan izin pelaksanaan pengabdian. Selain itu, UMS telah memberikan dukungan pendanaan kegiatan ini secara penuh. Tim pengebdian juga mengucapkan terima kasih kepada para peserta kegiatan ini.

\section{REFERENSI}

Anh, T., James, H., \& Pittock, J. (2018). Interaction Social Learning Through Rural Communities of Practice: Empirical Evidence from Farming Households in the Vietnamese Mekong Delta. Learning, Culture and Social Interaction, 16(October 2017), 31-44. https://doi.org/10.1016/j. lcsi.2017.11.002

Ariel, C., \& Iris, O. (2019). No Communication Without Manipulation : A causal-de fl Ationary View of Information. Studies in History and Philosophy of Science, 73, 34-43. https://doi.org/10.1016/j. shpsa.2018.06.003

Bang, J. Y., \& Nadig, A. (2020). An Investigation of Word Learning in the Presence of Gaze : Evidence from School-Age Children with Typical Development or Autism Spectrum Disorder. Cognitive Development, 54(December 2019), 100847. https://doi.org/10.1016/j.cogdev.2020.100847

Clark, A. S. (2016). Discourse is cultural : New Approaches to Discourse Analysis in the "Non-West" q. Language \& Communication, 50, 42-44. https://doi.org/10.1016/j.langcom.2016.09.001

Huda, M. (2018a). Blended Learning : Improvisasi dalam Pembelajaran Menulis Pengalaman. Lensa: Kajian Kebahasaan, Kesusastraan, Dan Budaya, 8(2), 117-130. https://doi.org/https://doi. org/10.26714/lensa.8.2.2018.117-130

Huda, M. (2018b). Strategi Berpikir Integratif dalam Pembelajaran Membaca Lintas Kurikulum di Sekolah Dasar. Jurnal Kredo, 1(2), 26-35. https://doi.org/ttps://doi.org/10.24176/kredo. v1i2.1995

Huda, M., Kustanti, E. W., \& Rufiah, A. (2019). Peningkatan Pemilihan Materi Ajar melalui Telaah Buku Teks bagi Guru Bahasa Indonesia di SMP Muhammadiyah Surakarta. Warta LPM, 22(2), 110-119. https://doi.org/https://doi.org/10.23917/warta.v22i2.8671

Kruel, D., Horne, K. Van, Steenis, E. Van, \& Penuel, W. R. (2018). Interaction The Material and Social Constitution of Interest. Learning, Culture and Social Interaction, (April), 0-1. https://doi. org/10.1016/j.lcsi.2018.04.010

Ma, Z., Li, C., Liu, Y., \& Zhang, J. (2018). The Transformation of Traditional Commercial Blocks in China : Characteristics and Mechanisms of Youthi Fi Cation. City, Culture and Society, (December 2017). 
Huda - Peningkatan Keterampilan Berbicara sebagai Upaya Kaderisasi Khatib ... https://doi.org/10.1016/j.ccs.2018.02.001

Raia, F. (2018). Learning, Culture and Social Interaction Identity, Tools, and Existential spaces. Learning, Culture and Social Interaction, (April), 0-1. https://doi.org/10.1016/j.lcsi.2018.04.014

Ram, D., Asaei, A., \& Bourlard, H. (2018). Phonetic Subspace Features for Improved Query by Example Spoken Term Detection. Speech Communication, 103, 27-36. https://doi.org/10.1016/j. specom.2018.07.001

Shao, X., \& Purpur, G. (2016). Effects of Information Literacy Skills on Student Writing and Course Performance. The Journal of Academic Librarianship. https://doi.org/10.1016/j. acalib.2016.08.006

Shishavan, H. B., \& Shari, F. (2016). The Refusal Speech Act in A Cross-Cultural Perspective : A study of Iranian English-Language Learners and Anglo-Australian Speakers. Language \& Communication, 47, 75-88. https://doi.org/10.1016/j.langcom.2016.01.001

Steinerov, J. (2016). Information Literacy Studies and Human Information Behaviour. Information Literacy Studies and HIB, 2, 53-69.

Turner, J. (2012). Academic Literacies: Providing a Space for the Socio-Political Dynamics of EAP. Journal of English for Academic Purposes, 11(1), 17-25. https://doi.org/10.1016/j. jeap.2011.11.007 